\title{
Pier Giorgio Borbone. Storia di Mar Yahballaha e di Rabban Sauma. Cronaca siriaca del XIV secolo
}

\section{Florence Jullien}

\section{(2) OpenEdition \\ 12 Journals}

Édition électronique

URL : http://journals.openedition.org/abstractairanica/40821

DOI : 10.4000/abstractairanica.40821

ISSN : 1961-960X

\section{Éditeur :}

CNRS (UMR 7528 Mondes iraniens et indiens), Éditions de l'IFRI

\section{Édition imprimée}

Date de publication : 1 décembre 2013

ISSN : 0240-8910

\section{Référence électronique}

Florence Jullien, « Pier Giorgio Borbone. Storia di Mar Yahballaha e di Rabban Sauma. Cronaca siriaca del XIV secolo", Abstracta Iranica [En ligne], Volume 32-33 | 2013, document 318, mis en ligne le 01 juillet 2016, consulté le 26 septembre 2020. URL : http://journals.openedition.org/abstractairanica/ 40821 ; DOI : https://doi.org/10.4000/abstractairanica.40821

Ce document a été généré automatiquement le 26 septembre 2020.

Tous droits réservés 


\title{
Pier Giorgio Borbone. Storia di Mar Yahballaha e di Rabban Sauma. Cronaca siriaca del XIV secolo
}

\author{
Florence Jullien
}

\section{RÉFÉRENCE}

Pier Giorgio Borbone. Storia di Mar Yahballaha e di Rabban Sauma. Cronaca siriaca del XIV secolo. Moncalieri, Lulu Press, 2010, 392 p.

Ce texte syriaque du XIV ${ }^{e}$ s. raconte la mission diplomatique du chrétien syro-oriental Sauma, choisi comme ambassadeur par le Khan Mongol Argun et envoyé en Europe ; son compagnon Yahballaha sera plus tard élu patriarche de l'Église d'Orient. Il s'agit d'un texte de grand intérêt sur la période mongole. En l'an 2000 avait paru la traduction française de l'ouvrage italien de P. G. Borbone par Egly Alexandre. L'A. offre ici l'édition du texte syriaque, qui n'avait pas fait l'objet d'une nouvelle édition depuis la traduction référente de J.-B. Chabot en français dans la Revue de l'Orient latin en 1893 : «Histoire du Patriarche Mar Jabalaha III et du moine Rabban Çauma » (p. 566-610) et en 1894 (p. 73-143, p. 235-300). Sont proposées d'excellentes notes de commentaire.

\section{AUTEURS}

FLORENCE JULLIEN

EPHE, Paris 